\title{
PENGARUH UKURAN PERUSAHAAN, TIPE INDUSTRI, GROWTH, DAN MEDIA EXPOSURE TERHADAP PENGUNGKAPAN TANGGUNG JAWAB SOSIAL PERUSAHAAN \\ (Studi Empiris pada Perusahaan yang Terdaftar di Bursa Efek Indonesia Tahun 2014- 2015)
}

\author{
*Harjanti Widiastuti ${ }^{1}$ \\ Evy Rahman Utami ${ }^{2}$ \\ Ridi Handoko ${ }^{3}$
}

\begin{abstract}
Akuntansi, Fakultas Ekonomi dan Bisnis, Universitas Muhammadiyah Yogyakarta
*widiascahyo@gmail.com
\end{abstract}

\begin{abstract}
This research aimed to analyze the influence of size, type of industry, growth, and media exposure on Corporate Social Responsibility Disclosure. The samples of this research are companies that has been listed in the Indonesia Stock Exchange between 2014 and 2015. Data in this study were obtained from annual reports and online newspapers. Regression analysis will be employed to answer the research question. The result showed that size and type of industry positively and significantly infuenced Corporate Social Responsibility (CSR) Disclosure. Growth negatively infuenced Corporate Social Responsibility (CSR) Disclosure dan media exposure has no influence on Corporate Social Responsibility (CSR).
\end{abstract}

Keywords: Corporate Social Responsibility Disclosure, size, type of industry, growth, and media expos

\section{PENDAHULUAN \\ Isu mengenai polusi, limbah, deplesi} sumber daya, kualitas \& keamanan produk, hak \& status pekerja, telah menarik perhatian berbagai kalangan, seperti masyarakat, investor, pemerintah, dan kreditor (Reverte 2009). Perusahaan terus didesak untuk bertanggung jawab tidak hanya kepada kreditor dan investor namun juga bertanggung jawab terhadap masalah lingkungan dan sosial (Reverte 2009). Kepedulian dan perhatian publik atas isu-isu lingkungan dan sosial dan meningkatnya pemberitaan isu-isu tersebut di media masa mendorong perusahaan melakukan pengungkapan sosial yang lebih luas (Deegan dan Gordon 1996). Kebijakan dan tindakan perusahaan untuk menangani isu-isu lingkungan dan sosial yang terjadi di lingkungan tempat perusahaan beroperasi dikenal dengan tangung jawab sosial perusahaan (Corporate Social Responsibility, selanjutnya disingkat CSR).

Pelaksanaan kegiatan CSR oleh perusahaan di Indonesia memiliki beberapa landasan hukum, diantaranya yaitu (1) Undang-Undang (UU) No. 40 Tahun 2007 tentang Perseroan Terbatas, (2) Peraturan Pemerintah (PP) No. 47 Tahun 2012 tentang Tanggung Jawab Sosial dan Lingkungan Perseroan Terbatas, (3) Undang-Undang No. 25 Tahun 2007 tentang Penanaman Modal, (4) Undang-Undang No.
32 Tahun 2009 tentang Perlindungan dan Pengelolaan Lingkungan Hidup, dan (5) Undang-Undang No. 22 Tahun 2001 tentang Minyak dan Gas Bumi. UU No. 40 Tahun 2007 dan UU No. 22 Tahun 2001 mewajibkan perusahaan yang menjalankan kegiatan usahanya di bidang dan atau berkaitan dengan sumber daya alam melaksanakan tanggung jawab sosial dan lingkungan. Pengungkapan pelaksanaan CSR perusahaan secara jelas diamanatkan dalam pasal 6 PP 47/2012 bahwa pelaksanaan CSR dimuat dalam laporan tahunan perseroan dan dipertanggungjawabkan kepada Rapat Umum Pemegang Saham (RUPS). Demikian juga dalam pasal 68 UU 32/2009 menyatakan bahwa setiap orang yang melakukan usaha dan/atau kegiatan memberikan informasi yang terkait dengan perlindungan dan pengelolaan lingkungan hidup secara benar, akurat, terbuka, dan tepat waktu. Dengan demikian, dasar hukum untuk pelaksanaan maupun pengungkapan CSR bagi perusahaan di Indonesia telah cukup memadai.

Meski landasan hukum praktik CSR dan pengungkapannya cukup kuat, pelaksanaan CSR perusahaan publik masih bervariasi, dari yang berkinerja CSR baik sampai yang melanggar praktik CSR. Beberapa perusahaan Publik yaang berkinerja CSR baik dan mendapatkan Indonesia Corporate 
Social Responsibility Awards (ICSRA) II tahun 2018 adalah PT Astra Agro Lestari Tbk sebagai peringkat pertama bidang pertanian (Kunjana 2018), dan tujuh besar perusahaan peraih ICSRA II 2018 yaitu PT Multi Bintang Indonesia Tbk, PT Bukit Asam (Persero) Tbk, PT Indofood Sukses Makmur Tbk., PT Bank CIMB Niaga Tbk, PT Modernland Realty Tbk, PT Indocement Tunggal Prakarsa Tbk, dan PT Bank Rakyat Indonesia (Persero) Tbk (Rahayu 2018). Penerima ICSRA dinilai berdasarkan publikasi kegiatan CSR (20\%), keterlibatan stakeholder (20\%), cakupan kegiatan CSR (40\%) meliputi kesehatan, lingkungan, pendidikan dan sosial, serta dampak jangka panjang CSR bagi masyarakat asaran (20\%) (Rahayu 2018). Sementara, beberapa pelanggaran praktik CSR oleh perusahaan publik di Indonesia misalnya dilakukan oleh PT Tuba Pulp Lestari Tbk yang dituntut dengan tuduhan pencemaran danau Toba (Sukmana 2016) dan mencaplok tanah adat (Munthe 2016); PT High Eagle Plantations Tbk dituding Greenpeace merusak hutan di Kalimantan dan Papua (Bayu 2016), dan PT Holcim Indonesia Tbk dituntut karena pencemaran udara (Arfah 2016). Fenomena tersebut mengindikasi bahwa landasan hukum tidak cukup memotivasi perusahaan melakukan praktik CSR sebaik mungkin, namun diperlukan komitmen manajemen dan pemegang saham perusahaan untuk menjadikan isu sosial sebagai prioritas dan bagian dari strategi bisnis perusahaan.

Praktik pengungkapan CSR yang dilakukan perusahaan publik juga masih bervariasi. Pengungkapan CSR yang bervariasi mengindikasi praktik CSR di perusahaan juga bervariasi. Riset sebelumnya mengenai pengungkapan CSR menunjukkan tingkat pengungkapan CSR bervariasi antar sektor industri perusahaan. Dari tabel 1 terlihat rata-rata pengungkapan CSR masih di bawah atau mendekati 50\%. Berdasarkan hasil riset-riset sebelumnya, variasi pengungkapan dapat disajikan pada tabel 1 sebagai berikut:

Tabel 1.1 Variasi Pengungkapan CSR dalam Laporan Tahunan Perusahaan Publik di Indonesia

\begin{tabular}{|c|c|c|c|c|}
\hline $\begin{array}{c}\text { Penelit } \\
\text { i }\end{array}$ & $\begin{array}{c}\text { Perioda } \\
\text { Penelitia } \\
\text { n }\end{array}$ & Sampel & $\begin{array}{c}\text { Mean } \\
\text { Pengu } \\
\text { ngkap } \\
\text { an } \\
\text { CSR }\end{array}$ & $\begin{array}{c}\text { Penguku } \\
\mathbf{r} \\
\text { Pengung } \\
\text { kapan } \\
\text { CSR }\end{array}$ \\
\hline $\begin{array}{l}\text { Sari } \\
(2012)\end{array}$ & $\begin{array}{l}2008- \\
2010\end{array}$ & $\begin{array}{l}\text { Perusaha } \\
\text { an } \\
\text { Manufak } \\
\text { tur }\end{array}$ & $21 \%$ & $\begin{array}{l}\text { GRI } 3 \text { (79 } \\
\text { item) }\end{array}$ \\
\hline $\begin{array}{l}\text { Kristi } \\
(2012)\end{array}$ & $\begin{array}{l}2010- \\
2011\end{array}$ & $\begin{array}{l}\text { Perusaha } \\
\text { an Publik }\end{array}$ & $30 \%$ & $\begin{array}{l}\text { GRI } 3 \text { (78 } \\
\text { item) }\end{array}$ \\
\hline $\begin{array}{l}\text { Ekowat } \\
\text { i, } \\
\text { Prasety } \\
\text { ono, } \\
\text { dan } \\
\text { Wuland } \\
\text { ari } \\
(2014)\end{array}$ & $\begin{array}{l}2010- \\
2012\end{array}$ & $\begin{array}{l}\text { Perusaha } \\
\text { an } \\
\text { Manufak } \\
\text { tur }\end{array}$ & $49 \%$ & $\begin{array}{l}\text { GRI } 3 \text { (78 } \\
\text { item) }\end{array}$ \\
\hline $\begin{array}{l}\text { Munsai } \\
\text { dah, } \\
\text { Andini, } \\
\text { dan } \\
\text { Supriya } \\
\text { nto } \\
(2016)\end{array}$ & $\begin{array}{l}2010- \\
2014\end{array}$ & $\begin{array}{l}\text { Perusaha } \\
\text { an } \\
\text { Property } \\
\text { dan Real } \\
\text { Estate }\end{array}$ & $49 \%$ & $\begin{array}{l}\text { GRI } 3 \text { (78 } \\
\text { item) }\end{array}$ \\
\hline $\begin{array}{l}\text { Solikha } \\
\text { h dan } \\
\text { Winarsi } \\
\text { h } \\
(2016)\end{array}$ & $\begin{array}{l}2011- \\
2013\end{array}$ & $\begin{array}{l}\text { Perusaha } \\
\text { an } \\
\text { Pertamba } \\
\text { ngan, } \\
\text { Energi, } \\
\text { Kimia, } \\
\text { Farmasi, } \\
\text { Kosmeti } \\
\text { k, } \\
\text { Makanan } \\
\text { dan } \\
\text { Minuma } \\
\text { n }\end{array}$ & $49 \%$ & $\begin{array}{l}\text { Environm } \\
\text { ental } \\
\text { dislosure } \\
\text { index } \\
\text { scorecard } \\
\text { (Rupley, } \\
\text { Brown, } \\
\text { dan } \\
\text { Marshall } \\
\text { 2012) }\end{array}$ \\
\hline $\begin{array}{l}\text { Indras } \\
\text { wari } \\
(2017)\end{array}$ & $\begin{array}{l}2012- \\
2015\end{array}$ & $\begin{array}{l}\text { Perusaha } \\
\text { an Food } \\
\text { dan } \\
\text { Beverage }\end{array}$ & $30 \%$ & $\begin{array}{l}\text { GRI } 4 \\
(125 \\
\text { item })\end{array}$ \\
\hline
\end{tabular}

Penelitian mengenai determinan pengungkapan CSR di sudah banyak dilakukan. 
Beberapa variabel yang diduga mempengaruhi variasi pengungkapan CSR perusahaan dan diteliti dalam penelitian ini adalah ukuran perusahaan, growth atau pertumbuhan perusahaan, tipe industri, dan media exposure. Variabel-variabel tersebut dipilih karena adanya ketidakkonsistenan atau sebaliknya justru konsistensi hasil penelitian-penelitian sebelumnya. Ukuran perusahaan diduga berpengaruh positif terhadap pengungkapan CSR. Perusahaan perlu menjaga hubungan baik dengan stakeholder melalui kegiatan CSR dan mensignalkan kegiatan tersebut melalui pengungkapan. Hasil penelitian relatif konsisten menunjukkan bahwa ukuran perusahaan berpengaruh positif terhadap pengungkapan CSR (Amalia 2013; Aslan dan Sigal 2016; Branco dan Rodrigues 2008; Chan, Watson, dan Woodliff 2014; Deegan dan Gordon 1996; Kristi 2012; Purwanto 2011; Reverte 2009; Sari 2012; Solikhah dan Winarsih 2016).

Tipe industri diduga berpengaruh terhadap pengungkapan CSR. Tipe industri tertentu memiliki aktivitas yang mungkin berdampak kurang baik terhadap lingkungan. Tipe industri disebut dalam beberapa istilah seperti kepekaan industri, sensitivitas industri. Beberapa peneliti yang menggunakan klasifikasi tipe industri high profile versus low profile menemukan bahwa tipe industri berpengaruh positif (Chan, Watson, dan Woodliff 2014; Deegan dan Gordon 1996; Hasnia dan Rofingatun 2017; Purwanto 2011; Reverte 2009), berpengaruh negatif (Sari 2012), dan tidak berpengaruh terhadap pengungkapan CSR (Amalia 2013).

Perusahaan bertumbuh memiliki trade off untuk melakukan CSR karena fokus pada investasi yang dilakukan. Di sisi lain, perusahaan bertumbuh memiliki aktivitas yang besar sehingga memiliki dampak lingkungan dan sosial yang luas. Penelitian sebelumnya menggunakan pertumbuhan penjualan sebagai pengukur growth menemukan hasil yang relatif konsisten bahwa growth tidak berpengaruh terhadap pengungkapan CSR (Ekowati, Prasetyono, dan Wulandari 2014; Hasnia dan Rofingatun 2017; Indraswari 2017; Sari 2012).

Media memiliki peran yang penting pada mobilisasi sosial, contohnya organisasi yang tertarik pada masalah-masalah lingkungan (Reverte 2009). Pemberitaan media merupakan mekanisma pengawasan publik yang memberikan tekanan kepada perusahaan untuk lebih peduli terhadap masalah lingkungan dan sosial sehingga mendorong perusahaan untuk lebih banyak melakukan pengungkapan CSR. Beberapa studi menemukan media exposure berpengaruh positif terhadap pengungkapan CSR (Branco dan Rodrigues 2008; Ekowati, Prasetyono, dan Wulandari 2014; Hasnia dan Rofingatun 2017; Kristi 2012; Reverte 2009), sedangkan (Solikhah dan Winarsih 2016) menemukan media exposure tidak berpengaruh terhadap pengungkapan CSR.

Tujuan penelitian ini adalah untuk menguji dan mendapatkan bukti empiris tentang pengaruh ukuran perusahaan, tipe industri, pertumbuhan, dan media exposure terhadap pengungkapan CSR. Secara lebih khusus, penelitian ini menginvestigasi mengenai pengaruh media exposure terhadap pengungkapan CSR. Penelitian ini memfokuskan pada media exposure dan penting dilakukan dengan beberapa alasan. Pertama, riset mengenai media exposure masih relatif terbatas dan hasilnya belum konsisten, sehingga perlu penelitian-penelitian. Kedua, penelitian yang menguji media exposure (Ekowati, Prasetyono, dan Wulandari 2014; Hasnia dan Rofingatun 2017; Kristi 2012) mendefinisi media exposure sebagai pengungkapan CSR dalam website perusahaan dan diukur dengan variabel dummy 1 bila perusahaan mengungkapkan CSR di website perusahaan, sebaliknya 0 bila perusahaan tidak mengungkapan CSR di website perusahaan. Definisi dan pengukuran ini menimbulkan kritik karena pengungkapan CSR di website perusahaan sebenarnya pengukur pengungkapan CSR bukan mengukur media exposure. Media exposure dalam penelitian ini lebih didefinisi dengan paparan media berkaitan dengan kegiatan CSR perusahaan dan diukur dengan jumlah publikasi kegiatan CSR pada media (dalam penelitian ini media online) (Branco dan Rodrigues 2008; Reverte 2009). Paparan media dalam hal ini surogasi dari pengawasan maupun penghargaan publik (masyarakat) atas kegiatan perusahaan. Studi yang mengukur media exposure dengan jumlah publikasi kegiatan CSR pada media adalah studi (Solikhah dan Winarsih 2016), namun menemukan media exposure tidak berpengaruh terhadap pengungkapan CSR. Hasil penelitian (Solikhah dan Winarsih 2016) tidak dapat dibandingkan dengan studi media exposure lainnya (Ekowati, Prasetyono, dan Wulandari 2014; Hasnia dan Rofingatun 2017; Kristi 2012) karena (Solikhah dan Winarsih 2016) menggunakan pengukur pengungkapan CSR yang berbeda. 


\section{KAJIAN PUSTAKA DAN PENGEMBANGAN HIPOTESIS}

\section{a. Teori-teori yang mendasari pengungkapan CSR}

Terdapat beberapa teori yang mendasari studi pengungkapan CSR perusahaan dalam penelitian ini, yaitu teori agensi, teori legitimasi, dan teori pensignalan. Teori keagenan dalam perusahaan menjelaskan bagaimana antara pemilik perusahaan (principal) dan manajemen (agen) berada pada titik temu. Hubungan antara pemilik perusahaan dan manajemen akan berpotensi menimbulkan konflik keagenan dan meningkatkan biaya keagenan apabila ada perbedaan kepentingan maupun asimetri informasi diantara keduanya (Jensen dan Meckling 1976). Kegiatan CSR memerlukan komitmen baik dari pemegang saham maupun manajemen. Apabila pemegang saham memiliki komitmen yang tinggi untuk mendukung kegiatan CSR maka kegiatan CSR akan masuk dalam kontrak pemegang sahammanajemen (misalnya kontrak kompensasi) sehingga manajemen menjadi lebih mudah melakukan kegiatan CSR. Dalam hal ini, pengungkapan sosial dan lingkungan digunakan sebagai salah satu dasar dalam menentukan kontrak utang, kontrak kompensasi manajerial, atau biaya politik (Reverte 2009).

Teori legitimasi memberikan penjelasan yang lebih komprehensif terkait dengan pengungkapan tanggung jawab sosial dan lingkungan karena secara eksplisit mengakui bahwa bisnis terikat oleh kontrak sosial dimana perusahaan setuju menjalankan berbagai aktivitas yang diinginkan secara sosial (Brown and Deegan 1998). (Gray, Kouhy, dan Lavers 1995) Pengungkapan tanggung jawab sosial dan lingkungan adalah cara untuk melegitimasi keberadaan keberlanjutan perusahaan untuk masyarakat. Teori legitimasi menjelaskan bahwa perusahaan mengungkapkan informasi sebagai sarana untuk menanggapi dan berpartisipasi dalam proses kebijakan publik (Patten 2002).

Teori pensignalan menjelaskan adanya informasi asimetri antara pemilik informasi (perusahaan) dengan pemakai informasi (stakeholder). Perusahaan akan mensignalkan kualitas perusahaan (berita baik) untuk menunjukkan keunggulannya dibanding perusahaan lain (Connelly et al. 2011). Teori signal menjelaskan dorongan perusahaan untuk mengkomunikasikan informasi positif sebagai upaya untuk menyampaikan kegiatan dan kebijakan perusahaan yang memiliki nilai tambah bagi perusahaan. Pengungkapan CSR merupakan upaya pensignalan kualitas perusahaan yang diharapkan dapat mengurangi asimetri informasi.

\section{b. Penurunan Hipotesis}

\section{Pengaruh Ukuran Perusahaan terhadap Pengungkapan CSR}

Dikaitkan dengan teori agensi, perusahaan yang mempunyai ukuran besar cenderung melakukan pengungkapan informasi yang lebih luas untuk mengurangi biaya keagenan (Sembiring 2005). Biaya keagenan timbul apabila ada ketidaksamaan kepentingan antara pemegang saham dan manajemen, termasuk dalam hal kebijakan CSR. Komitmen pemegang saham atas kebijakan CSR harus dimasukkan dalam kontrak dengan manajemen supaya manajemen tidak ragu melakukaan kegiatan CSR. Sebagai contoh, pemegang saham memasukkan kebijakan CSR perusahaan dijadikan salah satu indikator kinerja manajemen. Semakin besar ukuran perusahaan semestinya komitmen pemegang saham untuk mendorong kebijakan CSR perusahaan semakin besar sehingga ada alignment kepentingan dan biaya keagenan menjadi berkurang.

Pengaruh ukuran perusahaan terhadap pengungkapan CSR juga dapat dijelaskan oleh teori pensignalan. Perusahaan besar cenderung memiliki informasi asimetri yang semakin besar pula. Asimetri informasi timbul karena perusahaan besar memiliki aktivitas operasional yang memiliki dampak besar baik secara sosial maupun lingkungan dibanding perusahaan kecil. Upaya untuk mengurangi asimetri informasi diwujudkan dengan melakukan kegiatan CSR dan melakukan pengungkapan CSR secara lebih luas. Hasil penelitian sebelumnya menunjukkan bahwa ukuran perusahaan berpengaruh positif terhadap pengungkapan CSR (Amalia 2013; Aslan dan Sigal 2016; Branco dan Rodrigues 2008; Chan, Watson, dan Woodliff 2014; Deegan dan Gordon 1996; Kristi 2012; Purwanto 2011; Reverte 2009; Sari 2012; Solikhah dan Winarsih 2016). Berdasarkan penjelasan di atas, maka peneliti mengajukan hipotesis sebagai berikut:

\section{$\mathrm{H}_{1}$ : Ukuran perusahaan berpengaruh positif terhadap pengungkapan CSR.}

\section{Pengaruh Tipe Industri terhadap Pengungkapan CSR}

Tipe industri mengindikasi kegiatan operasi perusahaan dan dampaknya terhadap lingungan dn sosial. Salah satu jenis pengklasifikasian industri adalah industri high profile versus industri low profile. 
(Reverte 2009) menjelaskan bahwa industri high profile merupakan industri yang memiliki consumer visibility yang tinggi, tingkat risiko politik, dan tingkat kompetisi yang tinggi. Beberapa contoh industri yang masuk klasifikasi high profile adalah perusahaan minyak dan pertambangan, perusahaan farmasi, perusahaan hutan, perusahaan transportasi. Sebagai contoh, perusahaan minyak dan tambang adalah perusahaan eksplorasi yang berpotensi merusak lingkungan. Perusahaan farmasi mengolah bahan baku menjadi obat banyak berhubungan dengan bahanbahan kimia yang limbahnya berpotensi mecemaari lingkungan. Perusahaan dengan kategori high profile umumnya memperoleh sorotan lebih banyak dari masyarakat terkait dengan kepentingan lingkungan dan sosial.

Teori pensignalan dan teori legitimasi menjadi dasar dalam menjelaskan hubungan jenis industri high profile versus low profile dengan pengungkapan CSR perusahaan. Teori legitimasi erat hubungannya dengan norma-norma yang ada di masyarakat. Teori legitimasi melandasi adanya kontrak sosial antara perusahaan dengan masyarakat yang berdampak saling menguntungkan antara kedua belah pihak, salah satunya dengan melalui kegiatan CSR. Aktivitas operasi perusahaan berdampak terhadap lingkungan dan sosial masyarakat sehingga perusahaan perlu melakukan kegiatan CSR sebagai upaya meminimalkan konflik serta mendapat legitimasi dari masyarakat. Berdasar teori pensignalan, industri high profile sebagai industri yang banyak mendapat perhatian perlu mengurangi asimetri informasi berkaitan dengan dampak sosial dan lingkungan yang ditimbulkan oleh kegiatan operasi perusahaan dengan mengkomunikasikan kegiatan CSR yang dilakukan. Pengungkapan CSR merupakan sinyal positif yang diharapkan dapat diterima oleh stakeholder maupun masyarakat luas.

Hasil penelitian sebelumnya menunjukkan bahwa tipe industri berpengaruh positif terhadap pengungkapan CSR (Purwanto 2011; Chan, Watson, dan Woodliff 2014; Hasnia dan Rofingatun 2017; Reverte 2009; Deegan dan Gordon 1996). Perusahaan high profile ditemukan mengungkapkan lebih banyak informasi terkait aktivitas lingkungan dan sosial sebagai upaya mensignalkan tanggung jawab sosial perusahaan kepada para pemangku kepentingan. Berdasarkan penjelasan di atas, maka peneliti mengajukan hipotesis sebagai berikut:

\section{$\mathrm{H}_{2}$ : Tipe industri berpengaruh positif terhadap pengungkapan CSR.}

\section{Pengaruh Growth terhadap Pengungkapan CSR}

Pengaruh pertumbuhan perusahaan (growth) terhadap pengungkapan CSR dapat dijelaskan oleh teori keagemam dan pensignalan. Pemegang saham memiliki peran penting dalam kebijakan CSR perusahaan. Perusahaan dengan pertumbuhan penjualan tinggi, kinerja manajemen biasanya diukur dengan kinerja berbasis keuangan. Pengukuran kinerja manajemen yang fokus pada kinerja keuangan akan menurunkan motivasi manajemen melakukan kegiatan CSR. Namun hal ini tidak akan terjadi bila pemegang saham memiliki komitmen yang tinggi terhadap kegiatan CSR. Apabila pemegang saham memiliki komitmen tinggi terhadap kegiatan CSR, maka kebijakan CSR perlu dimasukkan dalam kontrak kompensasi untuk mengurangi biaya keagenan dengan manajemen.

Perusahaan yang mempunyai tingkat pertumbuhan yang tinggi akan mendapat banyak perhatian sehingga diprediksi perusahaan akan lebih luas dalam pengungkapan tanggung jawab sosial perusahaan (Sari 2012). Perusahaan yang mengalami pertumbuhan memiliki implikasi terhadap peningkatan ukuran perusahaan dan kinerja yang semakin membaik sehingga semakin menarik untuk para investor. Hal ini juga sesuai dengan teori pensignalan. Perusahaan yang bertumbuh biasanya fokus pada pencapaian kinerja keuangan semata. Oleh karena itu, ketika perusahaan bertumbuh tetap konsisten melakukan kegiatan CSR maka perusahaan akan mensinyalkan kegiatan CSR dalam bentuk pengungkapan yang lebih luas. Hasil penelitian sebelumnya menunjukkan growth tidak berpengaruh terhadap pengungkapan CSR (Ekowati, Prasetyono, dan Wulandari 2014; Hasnia dan Rofingatun 2017; Indraswari 2017; Sari 2012). Berdasarkan penjelasan di atas, peneliti mengajukan hipotesis sebagai berikut:

\section{$\mathrm{H}_{3}$ : Growth berpengaruh positif terhadap pengungkapan CSR.}

\section{Pengaruh Media Exposure terhadap Pengungkapan CSR}

Media exposure dalam penelitian ini didefinisi dengan kejadian atau kegiatan perusahaan berdampak sosial dan lingkungan yang diliput oleh media atau dipublikasikan oleh media. Media exposure 
mengindikasi tekanan publik maupun bentuk penghargaan publik atau masyarakat terhadap perusahaan melalui pemberitaan media. Pemberitaan media mengenai masalah-masalah lingkungan dan sosial yang ditimbulkan dari aktivitas perusahaan menjadi mekanisme pengawasan masyarakat dan memberikan tekanan perusahaan untuk lebih berhatihati dan peduli terhadap masalah lingkungan dan sosial serta meminimalkan konflik terkait masalah tersebut. Untuk meredam pemberitaan media, perusahaan akan melakukan kegiatan CSR dan melakukan pengungkapan CSR secara lebih luas demi keberlanjutan perusahaan. Hal ini sesuai dengan teori legitimasi. Sementara, pemberitaan media yang bersifat good news mengenai perusahaan merupakan penghargaan atau apresiasi terhadap kegiatan CSR perusahaan. Pemberitaan baik dalam media akan mendorong perusahaan untuk melakukan pengungkapan CSR dengan lebih luas dalam laporan tahunannya. Hal ini sesuai dengan teori pengsignalan.

Hasil penelitian sebelumnya menemukan bahwa media exposure berpengaruh positif terhadap pengungkapan CSR. (Kristi 2012; Ekowati, Prasetyono, dan Wulandari 2014; Hasnia dan Rofingatun 2017). Hal ini mungkin disebabkan pengukur media exposure adalah pengungkapan CSR di website perusahaan sehingga sebenarnya merupakan pengukuran pengungkapan CSR. Sedangkan (Solikhah and Winarsih 2016) yang mengukur paparan media dengan jumlah publikasi kegiatan CSR di media menemukan paparan media tidak berpengaruh terhadap pengungkapan CSR. Jumlah total liputan media meningkatkan visibilitas perusahaan dan menjadikan perusahaan sebagai objek perhatian publik dan sarana pengawasan yang efektif. Media exposure menjadi bagian dari proses pembangunan organisasi, menyusun norma-norma praktik CSR yang dapat diterima oleh masyarakat. Media tidak hanya memainkan peran pasif namun lebih aktif dalam membingkai informasi perusahaan menjadi lebih bernilai. Berdasarkan penjelasan di atas, peneliti mengajukan hipotesis sebagai berikut:

\section{$\mathrm{H}_{4}$ : Media Exposure berpengaruh positif terhadap pengungkapan tanggung jawab sosial perusahaan.}

\section{METODE PENELITIAN}

a. Sampel, metoda penyampelan, dan sumber data

Populasi penelitian ini yaitu perusahaan yang terdaftar di Bursa Efek Indonesia (BEI). Sampel yang digunakan dalam penelitian ini yaitu seluruh perusahaan yang terdaftar di Bursa Efek Indonesia (BEI) yang menerbitkan annual reports pada tahun 2014-2015. Metoda penyampelan menggunakan metoda purposive sampling dengan kriteria (1) mengungkapkan tanggung jawab sosial perusahaan dalam laporan tahunan perusahaaan, (2) melaporkan dalam mata uang rupiah, dan (3) perusahaan memiliki pertumbuhan penjualan (growth) positif. Data laporan tahunan perusahaan diperoleh dari publikasi di website Bursa Efek Indonesia (BEI). Data media exposure diperoleh media surat kabar online.

\section{b. Definisi dan Pengukuran Variabel}

1) Variabel dependen yang digunakan dalam penelitian ini adalah pengungkapan CSR. Instrumen pengukuran pengungkapan CSR yang akan digunakan dalam penelitian ini mengacu pada instrumen yang digunakan oleh (Sembiring 2005). Pengungkapan CSR terdiri tujuh kategori dengan 78 item pengungkapan sesuai GRI versi 3.0 (Sembiring 2005). Pengungkapan CSR perusahaan dinilai dengan indeks pengungkapan tanggung jawab sosial perusahaan. Analisis konten digunakan untuk melihat item-item pengungkapan tanggung jawab sosial perusahaan dalam laporan tahunan. Apabila item diungkapkan, diberikan skor 1, apabila tidak diungkapkan diberikan skor 0 . Pengungkapan tanggung jawab sosial perusahaaan dihitung dengan rumus:

CSRDI=Jumlah item yang diungkapkan / 78

2) Variabel Independen

a. Ukuran perusahaan

Ukuran perusahaan mengindikasi skala kegiatan operasi perusahaan. Semakin besar skala kegiatan operasi perusahaan semakin besar perusahaan Dalam penelitian ini ukuran perusahaan menggunakan logaritma natural total aktiva. Rumus yang akan digunakan untuk mengukur variabel ukuran perusahaan adalah:

Size $=$ Log natural (total asset)

b. Tipe Industri

Tipe industri yaitu karakteristik yang dimiliki perusahaan yang berkaitan dengan bidang usaha, risiko usaha, karyawan yang dimiliki dan lingkungan perusahaan. Skala pengukuran yang digunakan untuk tipe industri adalah skala nominal. Dummy variabel digunakan untuk klasifikasi industri high profile dan 
low profile. Nilai 1 diberikan untuk industri high profile yaitu perusahaaan yang masuk dalam perusahaan minyak dan pertambangan, kimia, hutan, otomotif, penerbangan, agribisnis, tembakau dan rokok, produk makan dan minuman, media dan komunikasi, energi (listrik), engineering, kesehatan/farmasi, serta transportasi dan pariwisata. Nilai 0 diberikan untuk industri low profile yaitu perusahaan yang masuk dalam bidang bangunan, properti, keuangan dan perbankan, pemasok peralatan medis, perusahaan ritel, tekstil dan produk tekstil, produk personal, dan produk rumah tangga.

c. Growth

Pertumbuhan perusahaan mencerminkan peningkatan kinerja keuangan perusahaan (Sari 2012). Pertumbuhan perusahaan menjadi salah satu pertimbangan para investor untuk mengalokasikan modalnya. Perusahaan yang memiliki kesempatan pertumbuhan yang tinggi, diharapkan akan menghasilkan keuntungan di masa depan, sehingga menarik para investor untuk menanamkan modalnya di perusahaan tersebut. Pertumbuhan perusahaan (growth) diukur dengan pertumbuhan penjualan perusahaan. Rumusnya sebagai berikut:

Penjualan $_{\mathrm{t}-1}$

Growth $=\quad\left(\right.$ penjualan $_{\mathrm{t}}-$ penjualan $\left._{\mathrm{t}-1}\right) /$

\section{d. Media Exposure}

Media mempunyai peran penting pada pergerakan mobilisasi sosial, misalnya kelompok-kelompok yang tertarik pada masalah lingkungan (Reverte 2009). Pemberitaan media juga memberikan tekanan kepada perusahaan untuk lebih perhatian terhadap masalah lingkungan dan sosial. Penelitian ini mengukur media exposure menggunakan jumlah berita atau artikel mengenai perusahaan yang diterbitkan oleh dua surat kabar di Indonesia, yaitu tribunnews dan kompas pada periode antara 1 Januari 2014 sampai 31 Desember 2015. Tribunnews mewakili media lokal, sedangkan kompas mewakili media nasional. Pengukuran dilakukan dengan memanfaatkan fasilitas pencarian yang tersedia di halaman web surat kabar tersebut. Sebuah pencarian dilakukan untuk setiap perusahaan, menggunakan nama perusahaan sebagai kata kunci. Hasil pencarian diperiksa untuk mengecualikan artikel yang tidak memiliki hubungan secara khusus dengan isu-isu tanggung jawab sosial perusahaan.

\section{c. Metoda Analisis Data dan pengujian hipotesis}

Pengujian hipotesis dalam penelitian ini menggunakan analisis regresi berganda. Hipotesis 1 sampai Hipotesis 4 terdukung apabila nilai sig $<0,05$ dan $\beta 1-\beta 4$ bernilai positif. Adapun persamaan regresi untuk pengujian hipotesis adalah sebagai berikut

$\mathrm{CRSD}=\alpha+\beta_{1}$ SIZE $+\beta_{2}$ TYPE +

$\boldsymbol{\beta}_{\mathbf{3}}$ GROWTH $+\boldsymbol{\beta}_{\mathbf{4}} \mathbf{M E}+\mathrm{e}$

Dengan keterangan: CRSD = Pengungkapan Tanggung Jawab Sosial Perusahaan; $\alpha=$ Konstanta; SIZE = Ukuran Perusahaan; TYPE = Tipe Industri; GROWTH = Pertumbuhan; ME = Media Exposure; $\beta 1-\beta 4$ $=$ Koefisien; $\mathrm{e}=$ error .

\section{HASIL DAN PEMBAHASAN}

\section{a. Statistik Deskriptif}

Objek dalam penelitian ini adalah seluruh perusahaan yang terdaftar di Bursa Efek Indonesia (BEI) periode 2014-2015. Dengan metoda penyampelan purposive, diperoleh sampel sebanyak 323 tahunperusahaan. Tabel 4.1 menyajikan hasil uji statistik deskriptif penelitian.

Tabel 4.1 Statistik Deskriptif Variabel penelitian

\begin{tabular}{|c|c|c|c|c|c|}
\hline Variabel & $\mathbf{N}$ & Mi & Ma & Mean & $\begin{array}{c}\text { Std. } \\
\text { Deviasi }\end{array}$ \\
\hline Perusaahaan & 32 & 17,9 & 30,1 & $\begin{array}{r}22,20 \\
4\end{array}$ & 1,85063 \\
\hline $\begin{array}{c}\text { Tkuran } \\
\text { Tipe Industri }\end{array}$ & 32 & 0 & 1 & 0,46 & 0,499 \\
\hline $\begin{array}{c}\text { Growth } \\
\text { Exposure }\end{array}$ & 32 & 0,00 & 1,90 & 0,220 & 0,26137 \\
\hline $\begin{array}{c}\text { Media } \\
\text { exposure } \\
\text { (high profile) }\end{array}$ & 14 & 0 & 10 & 1,32 & 1,882 \\
\hline $\begin{array}{c}\text { Media } \\
\text { exposure } \\
\text { (low profile } \\
\text { profile) }\end{array}$ & 17 & 0 & 10 & 1,31 & 2,000 \\
\hline $\begin{array}{c}\text { Cisclosure } \\
\text { Mxp }\end{array}$ & 32 & 0,08 & 0,68 & 0,384 & 0,11255 \\
\hline
\end{tabular}




\begin{tabular}{|c|c|c|c|r|c|}
\hline $\begin{array}{c}\text { CSR } \\
\text { Disclosure } \\
\text { (high profile) }\end{array}$ & 14 & 0,08 & 0,68 & 0,403 & 0,11854 \\
\hline $\begin{array}{c}\text { CSR } \\
\text { disclosure } \\
\text { (low profile) }\end{array}$ & 17 & 0,08 & 0,65 & $\begin{array}{r}0,369 \\
0\end{array}$ & 0,10506 \\
\hline
\end{tabular}

Berdasarkan tabel statistik deskriptif di atas, aset terendah dimiliki oleh PT Pembangunan Graha Lestari Tbk (PGLI), dan nilai aset tertinggi dimiliki oleh PT Bank Rakyat Indonesia (BBRI). Dari 323 perusahaan sampel, perusahaan yang masuk dalam kategori high profile sebesar $46 \%$ dari total sampel (148), sedangkan jumlah perusahaan yang masuk dalam kategori low profile sebesar $54 \%$ dari total sampel (175). Nilai rata-rata pertumbuhan penjualan perusahaan $22 \%$.

Variabel media exposure memiliki nilai rata-rata 1,32 minimum 0 yang dimiliki oleh perusahaanperusahaan yang kurang mendapat sorotan media. Sedangkan nilai tertinggi sebesar 10 yang dimiliki oleh perusahaan PT Tambang Batu Bara Bukit Asam Tbk, PT Telekomunikasi Indonesia Tbk, dan PT Indosat Tbk. Apabila perusahaan sampel diklasifikasi dalam industri low profile dan high profile, statistik deskriptif menunjukkan bahwa rata-rata media exposure pada industri high profile $(1,32)$ tidak jauh berbeda dengan industri low profile $(1,31)$.

Variabel CSR disclosure memiliki nilai rata-rata 38,46\% dengan tingkat pengungkapan CSR terendah adalah perusahaan PT Taisho Pharmaceutical Indonesia Tbk (sebesar 8\%), dan tertinggi adalah PT. Telekomunikasi Indonesia Tbk (sebesar 68\%). Apabila perusahaan sampel diklasifikasi dalam industri low profile dan high profile, statistik deskriptif menunjukkan bahwa industri high profile memiliki rata-rata pengungkapan CSR yang relatif lebih tinggi (40\%) dibanding industri low profile $(37 \%)$.

\section{b. Pengujian Hipotesis dan Pembahasan}

Sebelum melakukan pengujian dengan analisis regresi, peneliti telah melakukan uji asumsi klasik yang meliputi uji normalitas, uji multikolinieritas, uji autokorelasi, dan uji heteroskedastisitas. Hasil pengujian asumsi klasik menunjukkan bahwa residual regresi berdistribusi normal, tidak terjadi multikolinieritas, homoskedastisitas, dan terjadi autokorelasi. Masalah autokorelasi diatasi dengan melakukan koreksi HAC standard errors \& covariance (Newey test) atas model regresi, dan regresi dilakukan menggunakan program Eviews. Adapun hasil pengujian hipotesis (setelah koreksi HAC) disajikan pada tabel 4.2 sebagai berikut:

Tabel 4.2 Hasil Pengujian Hipotesis

\begin{tabular}{|c|c|c|c|c|}
\hline \multirow{2}{*}{ Variabel } & \multicolumn{2}{|c|}{$\begin{array}{r}\text { Unstandardized } \\
\text { Coefficients }\end{array}$} & \multirow{2}{*}{$\mathbf{T}$} & \multirow{2}{*}{ Sig } \\
\hline & B & Std.Error & & \\
\hline Konstanta & 0,089 & 0,096 & 1,170 & 0,356 \\
\hline $\begin{array}{c}\text { Ukuran } \\
\text { Perusahaan }\end{array}$ & 0,013 & 0,004 & 4,041 & 0,002 \\
\hline Tipe Industri & 0,039 & 0,012 & 3,208 & 0,001 \\
\hline Growth & $-0,089$ & 0,022 & $-3,879$ & 0,000 \\
\hline $\begin{array}{c}\text { Media } \\
\text { Exposure }\end{array}$ & 0,000 & 0,002 & 0,103 & 0,902 \\
\hline Adjusted $\mathrm{R}^{2}$ & 0,111 & & & \\
\hline F Statistik & 11,041 & & & \\
\hline $\begin{array}{c}\text { Sig (f- } \\
\text { statistik) }\end{array}$ & 0,000 & & & \\
\hline
\end{tabular}

1) Pengaruh Ukuran Perusahaan terhadap Pengungkapan Tanggung Jawab Sosial Perusahaan

Variabel ukuran perusahaan menunjukkan nilai koefisien regresi sebesar 0,013 dengan arah positif serta nilai sig 0,000 lebih kecil dari alpha 0,05. Dengan demikian, hipotesis satu terdukung, artinya ukuran perusahaan berpengaruh signifikan dan positif terhadap pengungkapan CSR. Semakin besar ukuran perusahaan maka aktivitas yang dilakukan oleh perusahaan juga semakin banyak sehingga pengungkapan aktivitas perusahaan semakin luas. Hal ini sesuai dengan teori keagenan bahwa perusahaan besar memiliki stakeholder yang semakin beragam sehingga kemungkinan timbul konflik keagenan juga semakin besar. Perusahaan besar tidak akan lepas dari tekanan para pemangku kepentingan, yaitu tekanan untuk melakukan pertanggung jawaban sosial. Perusahaan menggunakan pengungkapan kegiatan CSR sebagai mekanisma untuk mengurangi biaya keagenan. Hasil penelitian ini konsisten dengan penelitian (Purwanto 2011; Sari 2012; Kristi 2012; Amalia 2013; Solikhah dan Winarsih 2016; Chan, Watson, dan Woodliff 2014; Aslan dan Sigal 2016; 
Reverte 2009; Deegan dan Gordon 1996; Brancodan Rodrigues 2008).

2) Pengaruh Tipe Industri terhadap Pengungkapan Tanggung Jawab Sosial Perusahaan

Variabel tipe industri memiliki nilai koefisiesn regresi sebesar 0,039 dengan arah positif dan nilai sig 0,001 lebih kecil dari alpha 0,05, artinya hipotesis 2 terdukung. Hasil statistik deskriptif bahwa rata-rata pengungkapan CSR industri high profile lebih tinggi $(0,4030)$ dibanding industri low profile $(0,3690)$ mendukung hasil pengujian hipotesis dua. Pengaruh tipe industri terhadap pengungkapan tanggung jawab sosial menunjukkan bahwa perusahaan high profile mempunyai banyak sorotan karena terlibat dengan berbagai macam pemangku kepentingan sehingga pengungkapan sebagai alat komunikasi yang efektif. Perusahaan high profile lebih banyak mengungkapkan berbagai kegiatan perusahaan khususnya terkait sosial dan lingkungan. Aktivitas operasi perusahaan high profile (misal, industri pertambangan) dipandang memiliki dampak yang signifikan terhadap lingkungan dan masyarakat sehingga masyarakat merupakan stakeholder yang berkepentingan dengan keberadaan perusahaan. Penelitian ini sejalan dengan teori stakeholder bahwa perusahaan dalam menjalankan operasinya perlu mempertimbangkan kepentingan stakeholder utama, dan aktivitas CSR serta pengungkapan CSR merupakan upaya untuk memenuhi kepentingan stakeholder terutama masyarakat. Hasil penelitian ini konsisten dengan penelitian (Purwanto 2011; Chan, Watson, dan Woodliff 2014; Hasnia dan Rofingatun 2017; Reverte 2009; Deegan dan Gordon 1996).

3) Pengaruh Growth terhadap Pengungkapan Tanggung Jawab Sosial Perusahaan

Hasil penelitian menunjukkan bahwa growth berpengaruh negatif (koefisien regresi -0,089) terhadap pengungkapan CSR (nilai sig 0.000). Hasil ini tidak mendukung hipotesis 3 yang menyatakan bahwa growth berpengaruh positif terhadap pengungkapan tanggung jawab sosial perusahaan. Hal ini mengisyaratkan bahwa perusahaan yang mengalami pertumbuhan penjualan tinggi justru akan melakukan kegiatan CSR yang lebih sedikit, sehingga memiliki pengungkapan CSR yang rendah pula. Perusahaan yang memiliki pertumbuhan penjualan tinggi mengindikasikan perusahaan memfokuskan pada aktivitas operasi dan mengurangi kegiatankegiatan yang bersifat non operasi seperti kegiatan CSR. Perusahaan dengan pertumbuhan tinggi lebih memfokuskan pada kinerja keuangan untuk memenuhi kepentingan stakeholder utama yaitu investor, dan mungkin sedikit mengabaikan kepentingan stakeholder lainnya yaitu masyarakat. Hasil ini berlawanan dengan prediksi teori sinyal bahwa perusahaan dengan pertumbuhan yang tinggi akan mensinyalkan kegiatan CSR melalui pengungkapan. Hasil penelitian ini sejalan dengan penelitan (Indraswari 2017; Sari 2012; Ekowati, Prasetyono, dan Wulandari 2014; Hasnia dan Rofingatun 2017) bahwa belum semua investor menyadari pentingnya pengungkapan tanggung jawab sosial.

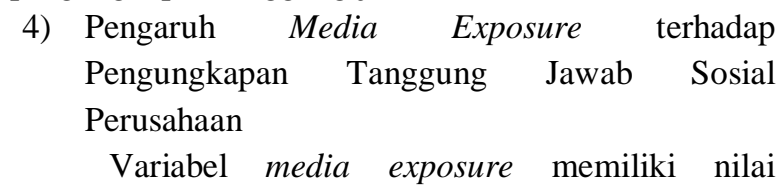
koefisien regresi sebesar 0,000 dengan arah positif dan nilai sig 0,918 yang lebih besar dari alpha $(0,05)$, artinya hipotesis 4 tidak terdukung. Hasil ini tidak konsisten dengan legitimasi maupun teori pensignalan. Variabel media exsposure tidak terdukung dalam penelitian ini kemungkinan karena kecilnya publikasi media mengenai kegiatan CSR perusahaan (rata-rata publikasi media hanya 1 publikasi pertahun di media online Tribun news dan Kompas). Kemungkinan lain adalah kemampuan jumlah publikasi oleh media online belum dapat mengukur media exsposure. Publikasi media sendiri ada yang bersifat positif (goodnews) dan pemberitaan negative (bad news). Pemberitaan positif oleh media boleh jadi karena permintaan perusahaan, sehingga sebenarnya bukan merupakan pengukur media exsposure. Pemberitaan negative mungkin pengukur media exsposure yang lebih baik karena mencerminkan tekanan atau pengawasan publik atas kegiatan CSR melalui media. Penelitian ini tidak membedakan pemberitaan negative dan positif. Dengan pengukuran media exsposure yang sama, hasil penelitian ini konsisten dengan penelitian (Solikhah dan Winarsih 2016).

\section{SIMPULAN}

Berdasarkan hasil pengujian yang telah peneliti lakukan dapat disimpulkan sebagai berikut. Pertama, ukuran perusahaan dan tipe industri berpengaruh signifikan dan positif terhadap pengungkapan tanggung jawab perusahaan di Indonesia. Kedua, growth berpengaruh signifikan dan negatif terhadap pengungkapan tanggung jawab sosial perusahaan. Ketiga, media exposure tidak berpengaruh terhadap pengungkapan tanggung jawab sosial perusahaan. Hal ini mengindikasi bahwa perusahaan memfokuskan pada kinerja keuangan sebagai upaya memenuhi kepetingan stakeholder utama yaitu investor dengan 
mengorbankan kepentingan stakeholder lainnya yaitu masyarakat. Investor juga kurang memiliki kepedulian terhadap kegiatan CSR perusahaan ketika perusahaan sedang mengalami pertumbuhan yang tinggi.

Penelitian ini memiliki keterbatasan dalam hal penggunaan regresi dengan asumsi common factor. Keterbatasan ini tentu perlu diperbaiki. Penelitian ini menggunakan jumlah berita tentang kegiatan CSR perusahaan pada media atau surat kabar online sebagai media exposure, tanpa membedakan apakah berita bersifat positif (good news, apresiasi atas kegiatan CSR perusahaan) atau bersifat negatif (bad news, dampak negatif atau masalah-masalah lingkungan dan sosial dari kegiatan perusahaan). Jumlah pemberitaan negatif nampaknya pengukur media exsposure yang lebih baik. Penelitian selanjutnya dapat membedakan media exposure dengan berita baik dan berita buruk untuk lebih dalam melihat efek media exposure terhadap kegiatan dan pengungkapan CSR perusahaan. Keterbatasan lainnya adalah jumlah publikasi media dalam penelitian ini hanya terbatas pada dua media online, yaitu Tribunnwes dan Kompas, berdasarkan subyektivitas peneliti. Penelitian selanjutnya dapat memperluan cakupan media online untuk menentukan jumlah publikasi kegiatan CSR di media.

\section{REFERENSI}

Amalia, Dewi. 2013. "Pengaruh Karakteristik Perusahaan Terhadap Corporate Social Responsibility Disclousure Di Bursa Efek Indonesia." Jurnal Media Riset Akuntansi 3 (1): 34-47.

Arfah, H. 2016. "Banyak Warga Meninggal Diduga Terkait Pencemaran Udara, Walhi Lakukan Investagi.” Kompas, April. http://regional.kompas.com/read/2016/04/02/160 72411/Banyak.Warga.Meninggal.Diduga.Terkai t.Pencemaran.Udara.Walhi.Lakukan.INvestigasi.

Aslan, M, and S Sigal. 2016. "Corporate Social Responsibility Research in Accounting: Evidence from Turkey." Accounting and Management Information Systems 15 (2): 40119.

Bayu, D. 2016. "Greenpeace Tuding Rantai Pasok IOI Group Rusak Hutan Di Kalimantan Dan Papua.” Kompas, September. http://nasional.kompas.com/read/2016/09/27/19 055661/greenpeace.tuding.rantai.pasok.ioi.group .rusak.hutan.di.kalimantan.dan.papua.

Branco, Manuel Castelo, and Lúcia Lima Rodrigues. 2008. "Factors Influencing Social Responsibility Disclosure by Portuguese Companies." Journal of Business Ethics 83 (4): 685-701. doi:10.1007/s10551-007-9658-z.

Brown, Noel, and Craig Deegan. 1998. "The Public Disclosure of Environmental Performance Information--a Dual Test of Media Agenda Setting Thoery and Legitimacy Theory." Accounting and Business Research 29 (1): 2141.

Chan, Mui Ching Carina, John Watson, and David Woodliff. 2014. "Corporate Governance Quality and CSR Disclosures." Journal of Business Ethics 125 (1): 59-73. doi:10.1007/s10551-0131887-8.

Connelly, Brian L., S. Trevis Certo, R. Duane Ireland, and Christopher R. Reutzel. 2011. "Signaling Theory: A Review and Assessment." Journal of Management $\quad 37 \quad$ (1): $39-67$. doi:10.1177/0149206310388419.

Deegan, Craig, and Ben Gordon. 1996. "A Study of the Environmental Disclosure Practices of Australian Corporations." Accounting and Business Reserach 26 (3): 187-99.

Ekowati, Lilis, Prasetyono, and Anis Wulandari. 2014. "Pengaruh Profitabilitas, Likuiditas, Growth, Dan Media Exposure Terhadap Pengungkapan Tanggungjawab Sosial Perusahaan (Studi Pada Perusahaan Manufaktur Yang Terdaftar Di BEI Tahun 2010 - 2012)." Simposium Nasional Akuntansi 17 Mataram, Lombok, no. 40: 1-24.

Gray, Rob, Reza Kouhy, and Simon Lavers. 1995. "Corporate Social and Environmental Reporting: A Review of The Literature and A Longitudinal Study of UK Disclosure." Accounting, Auditing \& Accountability Journal 8 (2): 47-77.

Hasnia, and S Rofingatun. 2017. "Pengaruh Profitabilitas, Likuiditas, Growth Dan Media Exposure Terhadap Pengungkapan Tanggung Jawab Sosial Perusahaan (Studi Empiris Pada Perusahaan Manufaktur Dan Perusahaan Jasa Yang Terdaftar Di Bursa Efek Indonesia Tahun 2013-2015)." Jurnal Akuntansi \& Keuangan Daerah 12: 56-71. 
Indraswari, I Gusti Ayu Laksmi. 2017. "Pengaruh Profitabilitas, Pertumbuhan Perusahaan, Kapitalisasi Pasar Dan Kepemilikan Saham Publik Pada Tingkat Pengungkapan CSR." Udayana, E-Jurnal Akuntansi Universitas 20: 1219-48.

Jensen, M. C, and W. H Meckling. 1976. "Theory of the Firm: Managerial Behavior, Agency Costs and Ownership Structure Theory of the Firm: Managerial Behavior, Agency Costs and Ownership Structure." Journal of Financial Economics 3: 305-60.

Kristi, Agatha Aprinda. 2012. "Faktor-Faktor Yang Mempengaruhi Pengungkapan Corporate Sosial Responsibility Pada Perusahaan Publik Indonesia." Jurnal Ilmiah Mahasiswa FEB Universitas Brawijaya 1: 27.

Kunjana, L Gora. 2018. "Sisihkan 300 Emiten, Astra Agro Raih Penghargaan CSR Terbaik.” Berita Satu.

http://www.beritasatu.com/ekonomi/480123sisihkan-300-emiten-astra-agro-raihpenghargaan-csr-terbaik.html .

Munsaidah, Siti, Rita Andini, and Agus Supriyanto. 2016. "Analisis Pengaruh Firm Size, Age, Profitabilitas, Leverage, Dan Growth Perusahaan Terhadap Corporate Social Rerponsibility (CSR) Pada Perusahaan Property Dan Real Estate Yang Terdaftar Di Bursa Efek Indonesia Pada Tahun 2010-2014." Journal of Accounting 2 (2).

Munthe, T. 2016. "Warga Tuding Tuba Pulp Caplok Tanah Adat." Kompas. http://regional.kompas.com/read/2016/03/04/102 00031/Warga.Tuding.Toba.Pulp.Caplok.Tanah. Adat.

Patten, Denis M. 2002. “Give or Take on the Internet: $\mathrm{Na}$ Examination of the Disclosure Practices of Insurance Web Innovators." Journal of Business $\begin{array}{llll}\text { Ethics } & 36 & \text { (3): }\end{array}$ https://link.springer.com/article/10.1023/A:1014 009229437.
Purwanto, Agus. 2011. "Pengaruh Tipe Industri, Ukuran Perusahaan, Profitabilitas, Terhadap Corporate Social Responsiblity." Universitas Diponegoro $\quad 8 \quad$ (1): $\quad 12-29$. doi:10.14710/jaa.v8i1.4344.

Rahayu, Eva. 2018. "72 Perusahaan Raih ICSRA II Tahun 2018." SWA. https://swa.co.id/swa/trends/72-perusahaan-raihicsra-ii-tahun-2018.

Reverte, Carmelo. 2009. "Determinants of Corporate Social Responsibility Disclosure Ratings by Spanish Listed Firms." Journal of Business Ethics 88 (2): 351-66. doi:10.1007/s10551-0089968-9.

Rupley, Kathleen Hertz, Darrell Brown, and R. Scott Marshall. 2012. "Governance, Media and the Quality of Environmental Disclosure." Journal of Accounting and Public Policy 31 (6): 610-40. doi:10.1016/j.jaccpubpol.2012.09.002.

Sari, Rizkia Anggita. 2012. "Pengaruh Karakteristik Perusahaan Terhadap Corporate Social Responsibility Disclosure Pada PerusahaanManufaktur Yang Terdaftar Di Bursa Efek Indonesia.” Nominal I (I): 124-40.

Sembiring, E. 2005. "Karakteristik Perusahaan Dan Pengungkapan Tanggung Jawab Sosial: Study Empiris Pada Perusahaan Yang Tercatat Di Bursa Efek Jakarta." In Simposium Nasional Akuntansi VIII.

Solikhah, B, and A Winarsih. 2016. "Pengaruh Liputan Media, Kepekaan Industri, Dan Struktur Tata Kelola Perusahaan Terhadap Kualitas Pengungkapan Lingkungan.” Jurnal Akuntansi Dan Keuangan Indonesia 13 (1): 52-69.

Sukmana, Yoga. 2016. "Stop Pencemaran Di Danau Toba, Rizal Ramli Minta Dua Perusahaan Besar Berhenti Beroperasi." Kompas. https://ekonomi.kompas.com/read/2016/01/09/1 41833726/Stop.Pencemaran.di.Danau.Toba.Riza 1.Ramli.Minta.Dua.Perusahaan.Besar.Berhenti.B eroperasi. 